\title{
Fuel and Electricity Reform for Economic Sustainability in the Gulf
}

\author{
Tom Moerenhout
}

\section{INTRODUCTION}

After the oil price started plummeting in the summer of 2014 and remained low throughout the next years (until 2017 when the OPEC Reference Basket average price recovered to USD 52), the fuel producing countries of the Gulf Cooperation Council started implementing energy pricing reforms. For many years, such pricing reforms had been planned and envisioned but, due to their quintessential role in the domestic political economies of Gulf countries, never really implemented. This is not unlike the broad and abstract goal of diversifying the economy away from oil to a more productive economy, and of changing the domestic social contract from one that is reliant on public employment and universal price support to one with private employment, market-based pricing structures and targeted social safety nets.

In recent years, since the oil price drop, all GCC countries have taken energy pricing reform measures (Fig. 8.1). Both fuel and electricity prices

T. Moerenhout $(\bowtie)$

Columbia University, School of International and Public Affairs, New York, NY, USA e-mail: tm2794@columbia.edu

(C) The Author(s) 2021

G. Luciani, T. Moerenhout (eds.), When Can Oil Economies Be

Deemed Sustainable?, The Political Economy of the Middle East, https://doi.org/10.1007/978-981-15-5728-6_8 


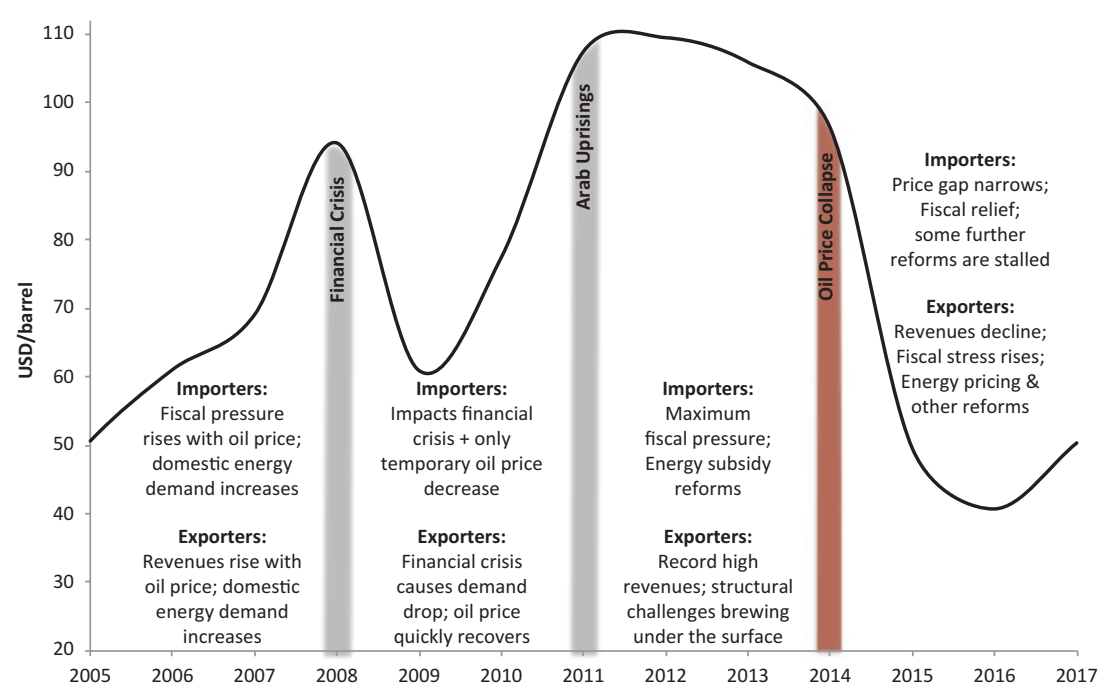

Fig. 8.1 Oil price movements and energy price reforms. (Source: Author)

have increased substantially. This chapter takes stock of those energy price increases and aims at giving a holistic account of where countries are at toward the end of 2018. After explaining the rationale for low energy prices, this chapter takes stock of fuel pricing reform and electricity tariff policies in all GCC countries.

\section{The Triple Rationale of Low Energy Prices}

There are three compelling reasons that make energy pricing reform so difficult in GCC countries. A first reason is the centrality of low energy prices in welfare protection and distribution. Governmental involvement in domestic pricing policies is legitimized across the developing world because energy has no close substitute and provides essential functions to human life (Maxwell 2010). Low energy prices are intended to alleviate poverty (Komives et al. 2008; Commander 2012) by safeguarding commodity prices, keeping inflation in check and sheltering consumers from the volatility of international commodity markets (Commander 2012; Fattouh and El-Katiri 2013; Kojima 2013; Overland 2010). In energy producing countries in the Gulf, pricing policies are an important part of the social contract. This means low prices can be considered as both a 
right of the people and an obligation of the government (Hartley and Medlock 2009; Luong and Weinthal 2010; Victor et al. 2011). GCC states are rentier states, in which the government is the principal receiver of oil revenues and the key responsible one to redistribute this income (Beblawi 1990). Increasing energy prices, ceteris paribus, represents a unilateral modification of the social contract.

A second rationale for low energy prices lies in their economic function. Low energy prices have been used to promote economic development by supporting factors of production in general and competitiveness for international trade in particular (Whitley and van der Burg 2015). In other words, low prices have been used as a part of industrial policy with the explicit goal of supporting export competitiveness of domestic industries (Commander 2012). Resource-rich countries in the Gulf in particular have used their hydrocarbon endowment to incentivize energy-intensive industrialization (IEA, OPEC, OECD and World Bank 2010). Energy pricing reforms have two types of impacts on firms. First, they affect firms directly by increasing their energy input cost. Second, there are indirect effects via the rise of prices from intermediary goods or services (that also rely on energy). These indirect effects can affect the supply chains of nonenergy intensive goods or services (Rentschler and Kornejew 2017). The sectors that suffer the most are logically energy-intensive industries such as heavy manufacturing, transport, petrochemicals, cement, aluminum and steel (Rentschler and Kornejew 2017; Bazilian and Onyeji 2012; Rentschler et al. 2017). These sectors are dominant industries for withindiversification in Gulf countries.

The third rationale is political. Given the potential social and economic impacts of pricing reform, implementing price increases is often politically costly and can even threaten political stability (Baig et al. 2007). It is now uniformly recognized that political economy factors are the primary barriers to reforming energy prices. Low energy prices are considered an instrument to stay in power and control political stakeholders through systems of patronage and rentierism (Cheon et al. 2014; Hartley and Medlock 2009; Overland 2010; Victor 2009). Governments use them to direct (financial) benefits to key political stakeholders, thereby consolidating power (Cheon et al. 2014). In rentier states like the ones in the GCC, low prices are used across the board to maintain the support of the public for the elite in power (Overland 2010). It should be no surprise that worldwide, fuel prices are lower in more centralized, non-democratic states (van Beers and Strand 2013). 


\section{The Sustainability Rationale for Energy Pricing ReForm, AND Results in THE GCC}

All GCC states reformed prices after the fuel price drop in 2014. Even though the nature of popular reception varies in different countries, energy price reforms seem to be one policy that authorities have recognized to be crucial for adjustment to falling oil revenues. The fiscal benefit from increasing energy prices is key to economic sustainability in two main ways: first because it gives governments more domestically sourced revenue, and second because it lowers demand of its key export commodity.

In terms of fiscal consolidation, overall pre-tax energy (gasoline, diesel and electricity) subsidies fell from $\$ 116$ billion in 2014 to $\$ 47$ billion in 2016 based on a price-gap model (IMF 2017). This type of subsidy quantification model reflects the opportunity costs of resources consumed domestically as opposed to being traded on the international market. That said, the fiscal capacity opened up by charging higher energy prices has been of crucial importance to GCC governments. Increasing energy prices has been considered as one of the most important measure to reduce nonwage recurrent spending (IMF 2017). The additional fiscal revenue has helped governments to prevent the international oil price collapse from threatening their domestic stability, while awaiting a recovery of oil prices that eventually started in 2017 (Fig. 8.2).

So far, it appears that fuel pricing reforms have paid off in terms of lowering demand. Average annual gasoline and diesel demand growth was around $6.2 \%$ and $4 \%$, respectively $(2010-2015)$ but slowed down to $0.4 \%$ and $-6 \%$ in 2016 . It is however difficult to attribute this slowdown to pricing reforms, as economic output also reduced over the last few years (APICORP 2017). In Saudi Arabia, gasoline demand leveled out even before the January 2018 reforms and diesel demand had already fallen $10 \%$. The latter can be attributed to less economic activity and the sourcing of more gas for power generation. In Oman, gasoline and diesel consumption fell by $6.2 \%$ and $7.2 \%$, respectively, from 2015 to 2016 (APICORP 2017). Unsurprisingly, given the relatively modest fuel price increases, the UAE has seen less demand reactions in recent years. On the contrary, fuel demand has actually increased in 2016.

The fiscal benefit of pricing reform and the reduction of demand are the main reasons to implement reforms for economic sustainability, but they are not the only ones (van Asselt and Skovgaard 2016). The fiscal crisis resulting from the oil price collapse has been in certain ways a 


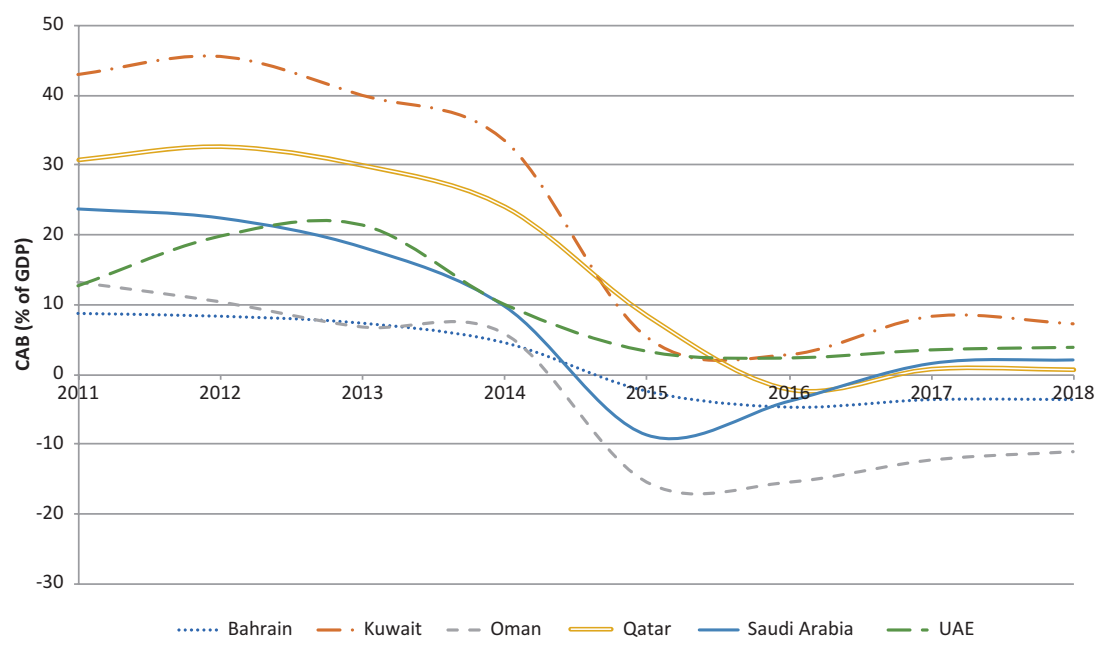

Fig. 8.2 Current account balance (\% of GDP, 2011-2018). (Source: IMF 2016 (up until 2013); IMF 2017 (as of 2014). Note: 2017 and 2018 are projections)

blessing to target excessive rentierism. Low domestic prices are correlated with higher levels of corruption through the involvement of government officials in black markets or industries that rely on cheap energy (Strand 2016).

Underpricing also leads to a misallocation of resources within the economy, often wrongly incentivizing energy intensive sectors and crowding out more productive sectors (Fattouh and El-Katiri 2013; IEA 2014; Maxwell 2010). Energy-intensive sectors tend to offer few and low-skilled jobs. In addition, in some countries with a lot of expatriate labor, it is less costly to focus on that labor as factor of production than it would be to focus on capital. Low-skilled labor is often abundant, while energy efficiency investments would be expensive and necessitate higher-skilled and therefore more expensive employees. In many countries, this has inevitably led to large shares of expensive public labor (Commander 2012), further burdening state coffers. The misallocation of energy resources has resulted in a rise in energy intensity of GDP and lowered incentives for energy efficiency, particularly in end-use sectors (Fattouh and El-Katiri 2013; IEA 2014; Anand et al. 2013).

A positive reallocation of resources within the economy does take time, and initially there may be a slowdown as sectors adapt, consolidate or close 
down. In an environment of low oil prices coupled with end-use energy price reforms, overall growth prospects in the medium-term have been subdued, though non-oil growth has been improving in some countries. Estimates from IMF staff show that the reforms indicated by GCC governments could lead to an increase of 1.7 to $6.6 \%$ of their non-oil GDP by 2020 based on each country's reform path, and an additional 1.5 to 3.0 percentage points of non-oil GDP would be generated with the introduction of VAT, as proposed by different countries and contained in the ratified GCC VAT agreement.

\section{Fuel Pricing Reform in the GCC}

While all GCC countries reformed energy prices, they did so in remarkably different ways. The UAE, Oman and Qatar were able to implement a periodic adjustment system that linked prices to international and regional prices. Kuwait tried to do the same but was unable to implement it. Like Saudi Arabia and Bahrain, they relied on one-off price increases. Unlike Kuwait, however, Saudi Arabia and Bahrain were able to implement more than just one ad hoc price adjustment. Below, we report price adjustments until June \& July 2018. In the summer of 2018 , the international oil price saw its highest price level since the 2014 plummet. In the fall of 2018 , the crude oil price fell again before recovering in the spring of 2019. During this time, ad hoc reformers implemented no further reforms, whereas gradual reforms kept adjusting prices in line with international price movements (both downward and again upward). In June 2019, price levels were almost identical in all GCC countries compared to those of the year before (and reported here).

\subsection{The 'Gradual' Fuel Price Reformers}

The UAE has been the first of GCC countries to seriously reform its fuel prices. In August 2015, transport fuel prices were liberalized and linked to international market prices using price formulae. As a result, gasoline price increased by $25 \%$ and diesel prices decreased by $29 \%$ (IMF 2015). Since, international market prices have been gradually going up and UAE prices have followed this trend. Fuel prices have been liberalized for all actors, including industry and commerce (Table 8.1).

Like many other countries, Oman first started raising energy prices for commerce and industry, before moving to residential consumers. Indicative 
Table 8.1 Fuel Prices in the UAE (July 2018)

\begin{tabular}{lcccc}
\hline Product & Unit & July 2015 & August 2015 & July 2018 \\
\hline Gasoline 98 & USD/L & 0.50 & 0.61 & 0.7 \\
Gasoline 95 & USD/L & 0.47 & 0.58 & 0.67 \\
Gasoline 91 & USD/L & 0.44 & 0.56 & 0.65 \\
Diesel & USD/L & 0.79 & 0.56 & 0.72 \\
\hline
\end{tabular}

Source: Collected by author

Table 8.2 Fuel Prices in Oman (continuously adjusted since January 2016)

\begin{tabular}{llcccc}
\hline Product & Unit & 2015 & Jan 2016 & Feb 2017 & Jun 2018 \\
\hline Gasoline 95 & USD/L & 0.31 & 0.42 & 0.47 & 0.59 \\
Gasoline 91 & USD/L & 0.31 & 0.36 & 0.45 & 0.56 \\
Diesel & USD/L & 0.38 & 0.42 & 0.53 & 0.65 \\
\hline
\end{tabular}

Source: Collected by author

of the fiscal need for reform in Oman is the fact that they already increased natural gas prices for industry and power producers in January 2015, well before reforms happened in the UAE and Saudi Arabia. It reformed fuel prices in the wake of Saudi reforms in January 2016. At the same time, it introduced a new pricing formula that links Omani prices to prices on the international market and in the UAE. Ever since, Oman has stuck to the formula and increased energy prices alongside international market prices (Table 8.2).

When reforming fuel prices, Oman also experienced opposition. In exchange, they installed a cap twice, and broke it twice. The second cap was set at 0.48 USD/L for regular gasoline. The government abolished that cap after having introduced the 'National Subsidy Scheme'. This scheme continues to provide subsidized fuel at a rate of 0.47 USD/L to less wealthy families. In total, 220,000 people signed up to the scheme in January 2018 (Times of Oman 2018). Under this scheme, nationals who own a car or boat and have a monthly income of below 950 riyals can apply for $200 \mathrm{~L}$ of subsidized fuel per month. The scheme only applies to regular gasoline, and when the price is above $0.47 \mathrm{USD} / \mathrm{L}$ (Al Mukrashi 2017; Sultanate of Oman 2018).

Like Oman, Bahrain and Saudi Arabia, Qatar also revised gasoline prices in early 2016. In a very early move, Qatar had reformed diesel prices 
Table 8.3 Qatar fuel prices (adjusted continuously since June 2016)

\begin{tabular}{llcccc}
\hline Product & Unit & 2015 & Jan 2016 & Jun 2017 & Jul 2018 \\
\hline Gasoline 97 & USD/L & 0.23 & $0.32(35 \%)$ & 0.43 & 0.56 \\
Gasoline 90 & USD/L & 0.28 & $0.36(30 \%)$ & 0.44 & 0.55 \\
Diesel & USD/L & 0.28 & $0.41(48 \%)$ & 0.45 & 0.56 \\
\hline
\end{tabular}

Source: Collected by author

already in 2014 (by about $50 \%$ for local companies but $75 \%$ for joint ventures) (Walker and Kovessy 2016). In May of the same year, the Qatari government announced plans to liberalize fuel prices and adjust them alongside international market prices, regional prices and cost of production-a move similar to the one taken by Oman and the UAE. This plan was implemented as of June 2016, after which there were monthly revisions to the fuel price. This move has been rather remarkable, given Qatar's high population-reserve ratio. Much like Kuwait, it could be expected that the Qatari government had less of a need to implement deep pricing reforms. One explanation, however, may be the impacts of Qatar's political isolation from other GCC countries, and the opportunism of its Government to use geopolitical threats to advance domestic reforms (Table 8.3).

\subsection{The 'Ad hoc' Fuel Price Reformers}

Saudi Arabia implemented significant energy pricing reforms in two episodes in January 2016 and January 2018. In January 2016, the Government reformed prices predominantly in reaction to the fiscal crisis as a result of the oil price drop. The Saudi Government targeted a full energy and water subsidy phase out by 2020 under its Vision 2030 plan, spearheaded by the then Deputy Crown Prince Mohammed bin Salman (IMF 2016) (Table 8.4).

The first stage of reforms was successful without introducing compensation measures or communication plans (APICORP 2018). After the first price reforms, energy demand growth decreased from $3.5 \%$ to $1.7 \%$ even though the net effect of pricing reforms is difficult to estimate as overall GDP went down as well (APICORP 2018). The anti-corruption campaign of Crown Prince Mohammed bin Salman was believed to help 
Table 8.4 Energy pricing reforms in Saudi Arabia (January 2016)

\begin{tabular}{llcc}
\hline Product & Unit & 2015 & 2016 \\
\hline Natural gas & USD/mmbtu & 0.75 & $1.25(67 \%)$ \\
Ethane & USD/mmbtu & 0.75 & $1.75(133 \%)$ \\
Gasoline 95 & USD/L & 0.16 & $0.24(50 \%)$ \\
Gasoline 91 & USD/L & 0.12 & $0.2(67 \%)$ \\
Diesel transport & USD/L & 0.07 & $0.12(79 \%)$ \\
Diesel industry & USD/barrel & 9.11 & $14.1(55 \%)$ \\
Arab light crude & USD/barrel & 4.24 & $6.35(50 \%)$ \\
Arab heavy crude & USD/barrel & 2.67 & $4.4(65 \%)$ \\
Kerosene & USD/barrel & 23.00 & $25.7(12 \%)$ \\
\hline
\end{tabular}

Source: Collected by author

public perception on the reforms. At the same time, reforms were unpopular, and inflation spiked right after reform.

In subsequent years, however, reform slowed down and was repeatedly postponed as the oil price recovered and the Government planned for compensation measures. There was a transparent commitment not to implement further reforms before the cash transfer scheme (citizen's income) was ready to be launched. At the same time, delays happened because the government was cautious not to slow down industrial output (Mahdi and Nereim 2017). In its latest budget, the Saudi government pushed back the plan to remove subsidies to 2025 (Gnana 2017). The January 2018 price rises mainly targeted gasoline prices, but also increased diesel prices for industry (Table 8.5).

As opposed to the first reforms, the second reforms were prepared with a large communication campaign and accompanied, as promised, by the cash transfer program. Citizen's Account started operating in January and aimed at distributing SAR 30 billion to 3.7 million households in 2018 . However, there were social media reactions against the cash transfers as the first round was not enough to compensate for the distributive losses (APICORP 2018). SAR 30 billion was allocated to Citizen's Account for 2018, but SAR 50 billion was going to military and civil servants (APICORP 2018). This indicates the relative importance of these stakeholders: the people matter, but perhaps the military and civil servants are more important to retain the ruling coalition. Saudi Arabia is also careful about its energy intensive industries. While there was indeed a pricing reform in 2018 for industrial diesel but not for transport diesel, the cost 
Table 8.5 Fuel pricing reforms in Saudi Arabia (percentage changes between brackets)

\begin{tabular}{llccc}
\hline Product & Unit & 2015 & Jan 2016 & Jan 2018 \\
\hline Natural gas & USD/mmbtu & 0.75 & $1.25(67 \%)$ & Unchanged \\
Ethane & USD/mmbtu & 0.75 & $1.75(133 \%)$ & Unchanged \\
Gasoline 95 & USD/L & 0.16 & $0.24(50 \%)$ & $0.54(127 \%)$ \\
Gasoline 91 & USD/L & 0.12 & $0.2(67 \%)$ & $0.37(83 \%)$ \\
Diesel transport & USD/L & 0.07 & $0.12(79 \%)$ & Unchanged \\
Diesel industry & USD/barrel & 9.11 & $14.1(55 \%)$ & $16.15(15 \%)$ \\
Arab light crude & USD/barrel & 4.24 & $6.35(50 \%)$ & Unchanged \\
Arab heavy crude & USD/barrel & 2.67 & $4.4(65 \%)$ & Unchanged \\
Kerosene & USD/barrel & 23.00 & $25.7(12 \%)$ & Unchanged \\
\hline
\end{tabular}

Source: Collected by author

per liter of industrial diesel remains lower than the one for transport diesel ( 0.10 USD/L versus 0.12 USD/L).

Like Oman, Bahrain had its first taste of energy pricing reforms by increasing natural gas tariffs for industrial users in March 2015. An earlier attempt to reform electricity prices for residential users had failed due to the opposition from members of parliament (APICORP 2018). Again, like Oman, it followed in the footsteps of Saudi Arabia in January 2016 and reformed fuel prices. It raised gasoline prices and planned for diesel price increases of $0.05 \mathrm{USD} / \mathrm{L}$ on an annual basis. Gasoline prices were not reformed annually. They remained stable until a next reform in January 2018.

For diesel, on the other hand, Government had been planning since 2013 to raise prices to 0.37 USD/L in January 2015, 0.42 USD/L in January 2016 and 0.47 USD/L in January 2017. These price rises were delayed but since January 2015, the annual price increase of 0.05 USD/L did happen. Fishermen were given support, but it did not cover their losses (Table 8.6).

The Kuwaiti government increased diesel prices by $200 \%$ in January 2015 , but immediately had to scale back reforms to $100 \%$ after parliamentary and other protests. In addition, large users (such as in industry) continued to receive diesel at the prior price. In September 2016, the Government implemented a gasoline price increase of about $70 \%$ on average and combined this with a plan to revise prices alongside international price movements. After heavy protests and a challenging of the price rise 
Table 8.6 Fuel prices in Bahrain (percentage changes between brackets)

\begin{tabular}{llccc}
\hline Product & Unit & 2015 & Jan 2016 & Jan 2018 \\
\hline Gasoline 95 & USD/L & 0.27 & $0.42(58 \%)$ & 0.53 \\
Gasoline 91 & USD/L & 0.20 & $0.33(56 \%)$ & 0.37 \\
Diesel & USD/L & 0.26 & 0.32 & 0.42 \\
\hline
\end{tabular}

Source: Collected by author

Table 8.7 Fuel prices in Kuwait

\begin{tabular}{llcc}
\hline Product & Unit & 2014 & Jan 2018 \\
\hline Gasoline 98 & USD/L & 0.27 & 0.50 \\
Gasoline 95 & USD/L & 0.20 & 0.32 \\
Gasoline 91 & USD/L & 0.18 & 0.26 \\
Diesel & USD/L & 0.17 & 0.35
\end{tabular}

Source: Collected by author

before Court, the government was able to maintain its gasoline price increase, but dropped the plan to adjust prices periodically (Moerenhout 2018). It is not planning any further price increases at the moment (Kuwait Times 2018) (Table 8.7).

\subsection{GCC Fuel Prices in Comparison}

In comparison to prices in other countries in the region, such as Jordan and average world prices, GCC countries still offer fuel at some of the lowest rates worldwide. Within the GCC, the UAE, Oman and Qatar have higher prices than other countries, even though Saudi Arabia and Bahrain have also invested heavily into cutting gasoline consumption (Fig. 8.3).

It appears fashionable to conclude that countries in the Gulf still have a long way to go in terms of fuel pricing reform. Experiences in fuel price changes across the world indeed show that changes may be reversed in the wake of popular protest or in the wake of changing international oil prices. This is of course no different in the case of GCC countries. That said, progress has been remarkable on two fronts. First, three countries were able to implement periodic fuel price adjustment systems and have stuck to revising fuel prices upward so far. Especially in Qatar, this has led to strong price increases over two years' time. That aside, Saudi Arabia and 


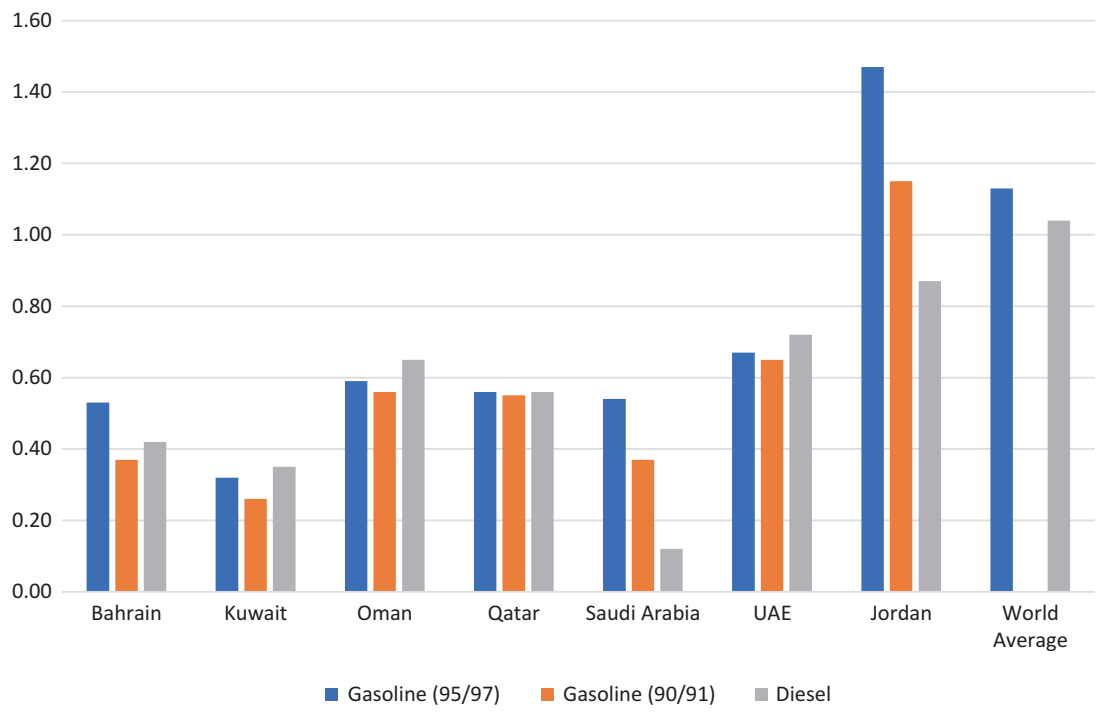

Fig. 8.3 Transport fuel prices (USD/L, July 2018). (Source: Author)

Bahrain have proven that one-off reforms can be followed up again, especially with the introduction of mitigation measures. Of all GCC-countries, Saudi Arabia has by far increased gasoline prices the most. Even if it came from far, the fact GDP/capita is lower and a rentier mentality potentially higher makes such adjustments all the more surprising (Fig. 8.4).

\section{GCC Electricity Pricing Reforms and Tariffs}

Most GCC countries have also increased electricity prices over the past few years. This has happened in various steps, to various extents and according to various pricing policies. Who bears the burden varies across countries, but in all countries, there are blocked tariffs and some form of crosssubsidization, either between expatriates and nationals, or between various consumer groups. Many electricity prices likely do not reach cost recovery levels. In the absence of production costs, governmental prices are often an (imperfect) proxy to cost-recovery levels. Most known electricity tariffs for government hover around $0.08 \mathrm{USD} / \mathrm{kWh}$. This is close to the official production cost figure quoted by the Bahraini Government of $0.77 \mathrm{USD} / \mathrm{kWh}$ (Fattouh et al. 2016). 


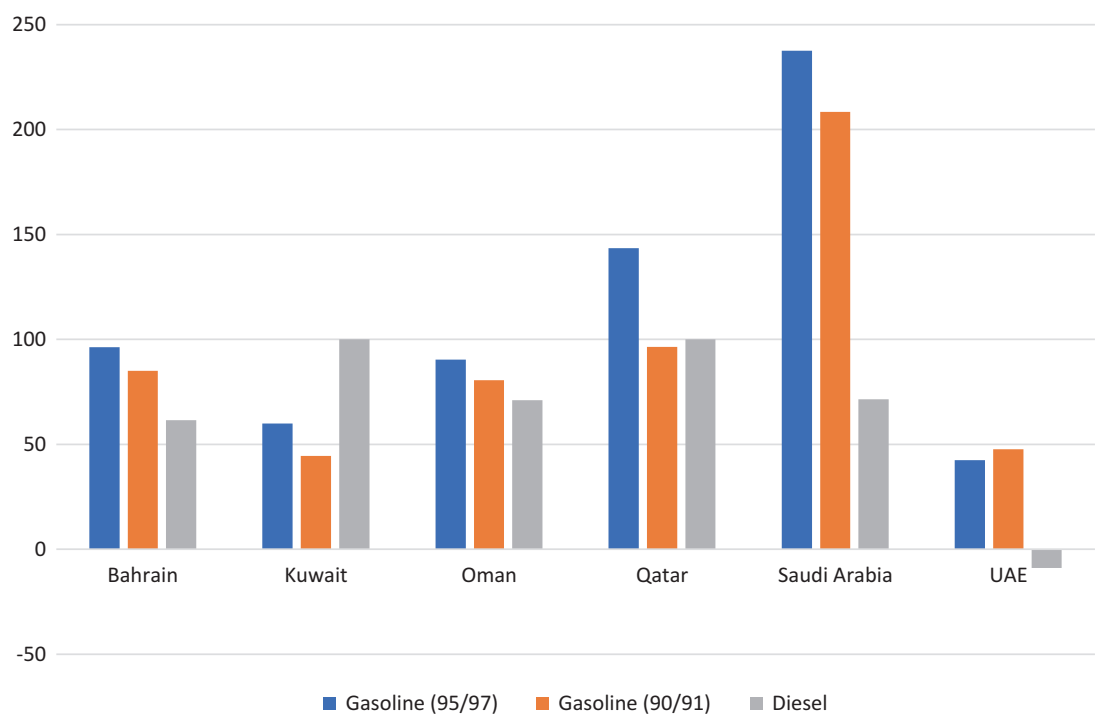

Fig. 8.4 Price changes (\%) before and after reforms (July 2018). (Source: Author)

\subsection{Cross-Subsidies Between Consumer Groups}

Many GCC countries provide some level of cross-subsidization to industry. Between the start of reforms in 2016 and January 2018, Saudi Arabia increased electricity tariffs for residential users $(<6000 \mathrm{kWh} /$ month $)$ by on average $260 \%$. Industrial users, however, were shielded from price rises, even if they still fall well below what the government pays. They now pay the same tariff as the lowest residential consumer group (Saudi Electric Company 2018). Similarly, in Dubai, industrial tariffs up to $10,000 \mathrm{kWh} /$ month are the same as the lowest residential consumer group (up to $2000 \mathrm{kWh} /$ month) (Dubai Electricity \& Water Authority 2018).

Some GCC countries have flat rates for industry, disregarding however much electricity is consumed per month. Oman has such a flat rate, even if the level of the rate depends on the time of year (it is double as high in the 4 warmest months of the year) (Qatar General Electricity \& Water Corporation 2018). Qatar also has a flat rate for industrial users, which is less than half the rate paid by Government and about half the rate paid by the highest residential consumer groups (Qatar General Electricity \& Water Corporation 2018). Kuwait also has flat rates for industry and 
commerce. The latter pays the same rate as the lowest residential consumer group, while industrial users still pay less than the highest residential users. Saudi Arabia's industrial tariff is also a flat rate and the same as the lowest residential consumer bracket (Saudi Electricity Company 2018). Besides industrial and commercial users, agricultural tariffs are also often cross-subsidized (for example in Oman, Saudi Arabia and Abu Dhabi).

Another type of cross-subsidization is between expatriates and nationals. In Abu Dhabi, nationals pay more for electricity when they consume more than $30 \mathrm{kWh} /$ day for apartments and $400 \mathrm{kWh} /$ day for villas. For expatriates, however, this is respectively $20 \mathrm{kWh} /$ day and $200 \mathrm{kWh} /$ day. Tariffs also diverge strongly. Nationals pay $0.018 \mathrm{USD} / \mathrm{kWh}$ or 0.02 USD $/ \mathrm{kWh}$ (depending on their consumption), while expatriates pay 0.073 USD/kWh or 0.083 USD/kWh (Abu Dhabi Distribution Company 2017). Bahrain also charges non-nationals and nationals with multiple accounts more than nationals with one single account (Bahrain Electricity and Water Authority 2018).

\subsection{Blocked Tariff Designs}

All GCC countries work with some type of blocked tariff designs to distinguish between high and low users. Blocked tariffs are particularly used in the residential sector and can vary by daily usage (Abu Dhabi) or monthly usage (others). The lowest consumption bracket in Qatar and Dubai is $2000 \mathrm{kWh} /$ month, in Kuwait, Bahrain and Oman $3000 \mathrm{kWh} /$ month, and in Saudi Arabia $6000 \mathrm{kWh} /$ month. Some jurisdictions also have additional subsidies for low income groups. For example, in Abu Dhabi, social cardholders that are also nationals pay nothing up to $333 \mathrm{kWh} /$ day and then $0.018 \mathrm{USD} / \mathrm{kWh}$ above that. Expatriates with social cards pay nothing up to $79 \mathrm{kWh} /$ day, after which they pay $0.073 \mathrm{USD} / \mathrm{kWh}$ (Abu Dhabi Distribution Company 2017).

Many GCC countries have flat rates for industry. Blocked tariff designs for industrial users are however present in Abu Dhabi in the case of large industrial users with an installed capacity of more than $1 \mathrm{MW}$ and only when they consume electricity during peak hours (Abu Dhabi Distribution Company 2017). This measure is to maintain the stability of the grid and adequacy of supply. As opposed to many countries, Bahrain also has blocked tariffs for Industry and Commerce that are similar to what residential consumer groups pay (Bahrain Electricity and Water Authority 
2018). This shows the particular controversy around residential electricity tariffs, particularly for less wealthy households with just one account.

\subsection{Electricity Pricing Reforms and Tariffs in Comparison}

All GCC countries have been reforming electricity prices since the drop of fuel prices. In Saudi Arabia, the recent reform of January 2018 hikes tariffs for the lower consumption bracket. In total, consumers up to $6000 \mathrm{kWh} /$ month pay 2.6 times more than in 2015 (APICORP 2018). In 2016, lowlevel consumers $(<4000 \mathrm{kWh} /$ month) were shielded from reforms when prices were raised by $2 / 3 \mathrm{rd}$ for the middle bracket (4001-6000 kWh/ month) and raised and unified for any consumer above that. The Authority of Electricity Regulation of Oman has cut subsidies to large consumers (using more than $150 \mathrm{mWh} /$ year) in Government, Commerce and Industry in January 2017. As a result, 10,000 of such users no longer receive subsidies and pay cost-reflective tariffs. Government hoped for savings of roughly RO 100 million annually from this measure alone (GI Consultancy 2017). Oman is currently conducting a review of how these measures impacted the specific large consumers. In the UAE, prices went up during the last years, but these mainly impacted expatriates. Also in Qatar, an unexpected tariff increase in October 2015 was followed by others in subsequent years. Kuwait also increased tariffs, starting with the commercial sector (Figs. 8.5 and 8.6).

\section{Commerce, Industry and Energy Pricing Reforms}

Commercial and industrial stakeholders have not been saved from reforms, and the question remains as to which place will be given to energy intensive industries in the various economic diversification plans of GCC states. A pertinent concern for energy-intensive industries that have been beneficiaries of the state's largesse in the form of subsidized energy input will be how to address the effect of new prices on their production activities, while governments seek to tackle possible cost-push inflation and the burden on consumers in addition to advancing their economic diversification agenda.

So far, little attention has been given to industrial users and specifically energy-intensive industries in terms of compensation measures for energy pricing reforms. These industries will have the greatest interest in preserving low energy prices not only because they have been accustomed to years 


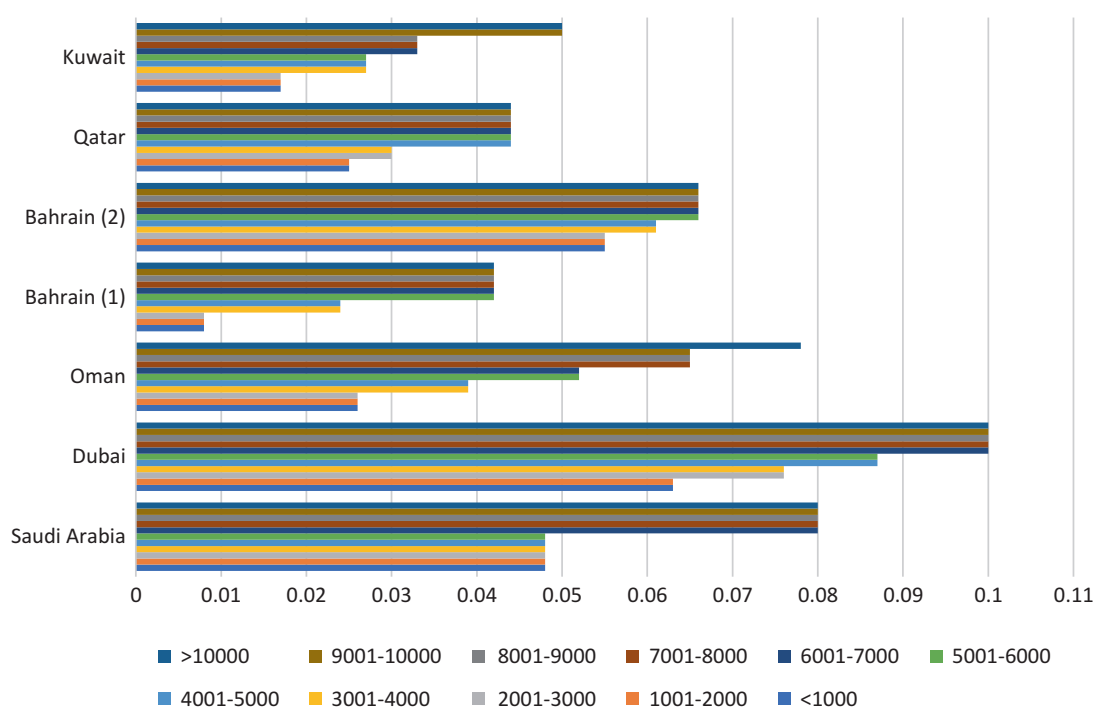

Fig. 8.5 Residential electricity block tariffs in the GCC (July 2018). (Source: Collected by author. Note: Bahrain $(1)=$ Bahraini nationals with only one account; Bahrain $(2)=$ Non-Nationals and Bahraini nationals with multiple accounts)

of low prices following long-time government strategies to maximize the country's comparative advantage. Well-designed policy plans can help to consolidate the gains from the upward revision of energy prices, while also allowing enough space to producers and consumers to adjust to new economic realities.

Energy intensive industries take up a unique position in the political economies of many Gulf countries. From one side, they are used to recycle oil rents and are often closely linked to government (either informally or through the use of state-owned enterprises). From another side, they mainly benefit rich owners, while they do not offer large employment possibilities to the well-educated youth. Rather they rely on migrant labor and leave the public sector to deal with the employment of nationals. As a result, the performance (and survival) of energy intensive industries is determined by two opposing forces: one that seeks to maintain rents to keep politically connected businesses in check, and one that seeks to reform industrial prices to avoid deeper residential price increases. 


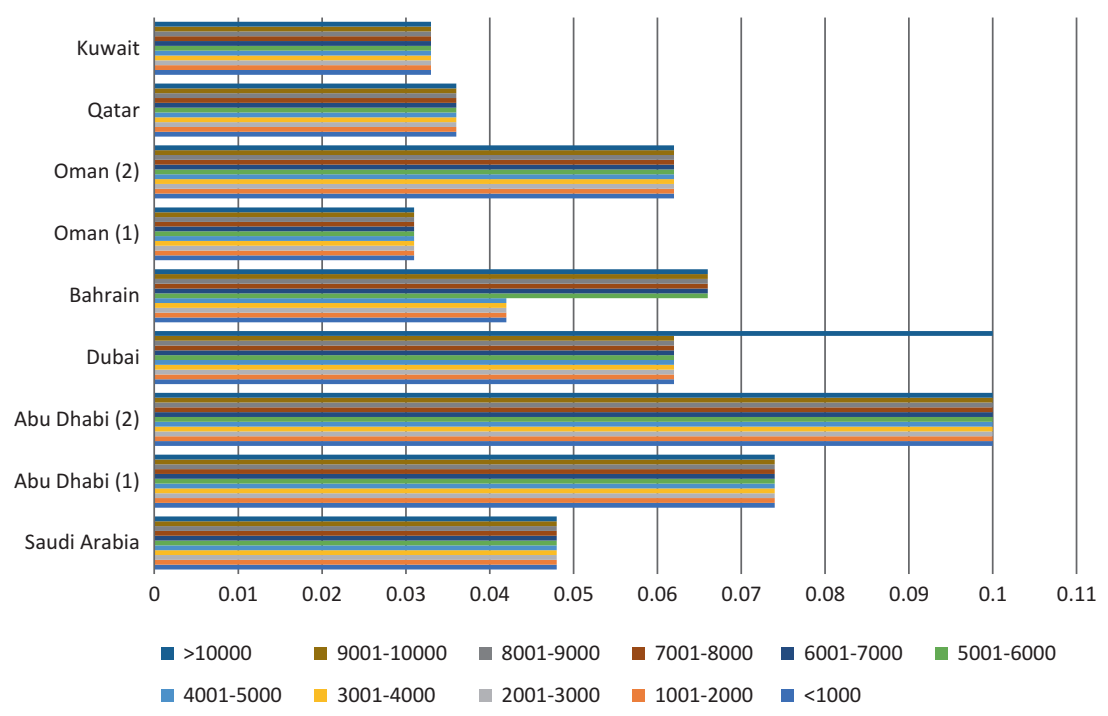

Fig. 8.6 Industrial electricity tariffs in the GCC. (Source: Collected by author. Note: Oman $(1)=8$ non-summer months; Oman (2) = 4 summer months; Abu Dhabi $(1)=$ for industrial users with installed capacity below $1 \mathrm{MW}$ and those with installed capacity above $1 \mathrm{MW}$, but outside of peak hours; Abu Dhabi (2) = for industrial users with installed capacity above $1 \mathrm{MW}$ and consuming power during peak hours)

In some ways, residents benefit from low energy prices given to industries: directly, when they purchase goods from these companies, or indirectly, when other goods use energy intensive products as intermediary inputs. These inflationary effects can seep through the value chain and add to the costs of regular residents. At the same time, however, residents also compete with industries and commerce for cheap energy. Since they do not benefit from private sector employment much, the vast value of low energy prices stays with high-level managerial positions. As a result, it could be expected that when public discontent threatens political stability, commercial and industrial tariffs will be adjusted upward first (like it has happened in many other countries). On the contrary, when the wider public is able to accept reforms, residential consumers will also be targeted. This political reality does not help to design a comprehensive plan for economic diversification. It does, however and again, prove the quintessence of developing more targeted welfare protection mechanisms, such as cash transfers. 


\section{Conclusion}

As a result of the oil price collapse in 2014, 2015 and 2016, all GCC countries have implemented considerable energy pricing reforms. While the level of depth of reforms has depended on various factors, such as resource reserves, population size, GDP per capita and geopolitical drivers, all countries have stuck to implemented reforms to date (June 2019). This is noteworthy, as it often happens that pricing reforms in resourcerich countries are reversed when the international price increases again, as was the case in 2017 and 2018.

GCC countries have chosen different strategies to adjust fuel prices. Saudi Arabia, Kuwait and Bahrain have opted for ad hoc pricing reforms, whereas the UAE, Qatar and Oman have implemented an automatic price setting mechanism that links domestic prices to regional and international oil price movements. The literature suggests that the implementation of an automatic price adjustment mechanism is more sustainable in the long run. However, it is important to observe the results from ad hoc price increases as well, particularly in Saudi Arabia, which has seen the largest percentage increase in domestic fuel prices. Relative to regional peers and global averages, GCC countries still have rather low fuel prices, but it is uncontestable that the price gap between domestic and international prices has been significantly reduced in all countries. Similar to fuel, GCC countries have also all implemented electricity pricing reforms since the collapse of the oil price.

The price increases have contributed to economic sustainability in two main ways. First, they have allowed governments to raise more domestic revenue and, as a result, prevent a further collapse of their already sizeable deficits in the wake of the oil price collapse. This can be reasonably linked to domestic stability more generally. Since conflict has longer-term impacts on economic sustainability, the ability to mitigate international oil price fluctuations via domestic pricing reforms is a rather essential tool to protect an economic collapse. Second, they have led to a reduction of energy demand in many (but not all) GCC countries. It is however difficult to attribute this slow down to pricing reforms, as economic output also reduced in a general economic downturn.

Despite these advantages, the impact of pricing reforms on economic sustainability suffers from a potential temporal conundrum. Besides the aforementioned short-term benefits, pricing reforms should also restore a more proper allocation of resources in the economy. Short-term effects, 
Table 8.8 Transition process from allocation state to productive economy

\begin{tabular}{|c|c|c|}
\hline Allocation state & Transition process & Productive economy \\
\hline $\begin{array}{l}\text { In-kind benefits with } \\
\text { infrequently changed } \\
\text { ad hoc pricing }\end{array}$ & $\begin{array}{l}\text { Pricing reforms (energy, food, } \\
\text { other) \& introduction of value } \\
\text { added \& excise taxes }\end{array}$ & $\begin{array}{l}\text { Market-based pricing that } \\
\text { incentivizes responsible } \\
\text { consumption }\end{array}$ \\
\hline $\begin{array}{l}\text { Universal and } \\
\text { untargeted transfers }\end{array}$ & $\begin{array}{l}\text { Ability to collect social data \& } \\
\text { design policies accordingly }\end{array}$ & $\begin{array}{l}\text { Targeted welfare subsidies and } \\
\text { social safety nets }\end{array}$ \\
\hline $\begin{array}{l}\text { Mostly public } \\
\text { employment of } \\
\text { nationals }\end{array}$ & $\begin{array}{l}\text { Labor market, education and } \\
\text { immigration policy reform to } \\
\text { 'nationalize' private sector } \\
\text { employment }\end{array}$ & $\begin{array}{l}\text { Mostly private sector } \\
\text { employment and narrowing of } \\
\text { public-private wage gap }\end{array}$ \\
\hline $\begin{array}{l}\text { No or low taxation on } \\
\text { business }\end{array}$ & $\begin{array}{l}\text { Levy of corporate taxes and } \\
\text { enhanced policies aimed at } \\
\text { private sector }\end{array}$ & $\begin{array}{l}\text { Interdependency between } \\
\text { private sector, citizens and } \\
\text { government }\end{array}$ \\
\hline $\begin{array}{l}\text { No or low taxation on } \\
\text { income }\end{array}$ & $\begin{array}{l}\text { Introduction of progressive } \\
\text { income taxation scheme }\end{array}$ & $\begin{array}{l}\text { Progressive income taxes to } \\
\text { finance government's social } \\
\text { responsibility }\end{array}$ \\
\hline
\end{tabular}

Source: Author

however, can be negative, particularly in countries that try to use withinsector diversification to add productivity to their allocation state models. If countries adjust prices too quickly, they may undermine their own comparative advantage and they may change the social contract unilaterally, provoking public discontent. All-in-all, now the oil price has picked up, we may see a slowing down of pricing reforms among ad hoc reformers to restore stability for residential and industrial consumers. While the need for counter-cyclical economic and fiscal policies is widely recognized, this is not realistic in the GCC given the domestic political economy. This type of policy-making can only be achieved when the hydrocarbon-rich countries of the GCC simultaneously advance on other much-needed reforms, including the development of targeted welfare protection, taxation reform, education reform and, most importantly, labor market reform (Table 8.8).

\section{REFERENCES}

Abu Dhabi Distribution Company. 2017. "Slab Tariff," https://www.addc.ae/ en-US/residential/Documents/02-English.pdf.

Al Mukrashi, Fahad. 2017. "Oman Introduces New Fuel Subsidy Scheme." GulfNews, December 16, 2017. https://gulfnews.com/news/gulf/oman/ oman-introduces-new-fuel-subsidy-scheme-1.2141838. 
Anand, Rahul, David Coady, Adil Mohommad, Vimal Thakoor, and James P. Walsh. 2013. "The Fiscal and Welfare Impacts of Reforming Fuel Subsidies in India." IMF Working Paper 12/128. IMF. https://www.imf.org/en/Publications/WP/Issues/2016/12/31/ The-Fiscal-and-Welfare-Impacts-of-Reforming-Fuel-Subsidies-in-India-40593. Apicorp. 2017. "Lowdown in GCC Domestic Fuel Consumption: Temporary Slump or New Reality?". Apicorp Energy Research 2, no. 11: 3.

- 2018. "Saudi Energy Price Reform Getting Serious." Apicorp Energy Research 3, no. 5: 3 .

Asselt, Harro van, and Jakob Skovgaard. 2016. "The Politics and Governance of Energy Subsidies." In The Palgrave Handbook of the International Political Economy of Energy, 269-88. Palgrave Handbooks in IPE. Palgrave Macmillan, London. https://doi.org/10.1057/978-1-137-55631-8_11.

Bahrain Electricity and Water Authority. 2018. "Electricity and Water Tariffs,". http://www.ewa.bh/en/Customer/BillsTariffs/electricity-water-tariffs.

Baig, Taimur, Amine Mati, David Coady, and Joseph Ntamatungiro. 2007. "Domestic Petroleum Product Prices and Subsidies: Recent Developments and Reform Strategies.” IMF Working Paper 07/71. IMF. https://www.imf.org/ en/Publications/WP/Issues/2016/12/31/Domestic-Petroleum-ProductPrices-and-Subsidies-Recent-Developments-and-Reform-Strategies-20608.

Bazilian, Morgan, and Ijeoma Onyeji. 2012. "Fossil Fuel Subsidy Removal and Inadequate Public Power Supply: Implications for Businesses.” Energy Policy 45, no. Supplement C: 1-5. https://doi.org/10.1016/j.enpol.2012.02.057.

Beblawi, Hazem. 1990. "The Rentier State in the Arab World.” In The Arab State, edited by Giacomo Luciani, 85-98. University of California Press.

Cees van Beers, and Jon Strand. 2013. "Political Determinants of Fossil Fuel Pricing." The World Bank Development Research Group.

Cheon, Andrew, Maureen Lackner, and Johannes Urpelainen. 2014. "Instruments of Political Control: National Oil Companies, Oil Prices, and Petroleum Subsidies." Comparative Political Studies, 1-33.

Commander, Simon. 2012. "A Guide to the Political Economy of Reforming Energy Subsidies.” IZA policy paper No. 52. http://ftp.iza.org/pp52.pdf.

Dubai Electricity \& Water Authority. 2018. "Slab Tariff,". https://www.dewa. gov.ae/en/customer/services/consumption-services/tariff.

Fattouh, Bassam, and Laura El-Katiri. 2013. "Energy Subsidies in the Middle East and North Africa." Energy Strategy Reviews 2: 108-15.

Fattouh, Bassam, Tom Moerenhout, and Anupama Sen. 2016. "Striking the Right Balance? GCC Energy Pricing Reforms in a Low Price Environment." Oxford Energy Comment. Oxford: Oxford Institute for Energy Studies. https://www.oxfordenergy.org/wpcms/wp-content/uploads/2016/04/ Striking-the-Right-Balance-GCC-Energy-Pricing-Reforms-in-a-Low-PriceEnvironment.pdf. 
GI Consultancy. 2017. “Oman Energy Master Plan: Two Years on - What Has Happened?". http://www.thegulfintelligence.com/mediafiles/cataloguedatas heet/8a911c5f-8437-4db4-bf42-9153fb8006fe.pdf.

Gnana, Jennifer. 2017. "Saudi Arabia Extends Deadline for Energy Price Reform." The National. https://www.thenational.ae/business/energy/ saudi-arabia-extends-deadline-for-energy-price-reform-1.689473.

Hartley, Peter R., and Kenneth B. Medlock. 2009. "Potential Futures for Russian Natural Gas Exports." The Energy Journal 30, no. Special Issue: 73-96.

IEA. 2014. "World Energy Outlook 2014." Paris: OECD/IEA. http://www. worldenergyoutlook.org/resources/energysubsidies/.

IEA, OPEC, OECD, World Bank Joint Report. 2010. "Analysis of the Scope of Energy Subsidies and Suggestions for the G-20 Initiative." Report prepared for submission to the G-20 Summit Meeting Toronto (Canada), 26-27 June 2010. http://www.oecd.org/env/45575666.pdf.

IMF. 2016. "2016 Article IV Consultation: Saudi Arabia,". http://www.imf.org/ external/pubs/ft/scr/2016/crl6326.pdf.

—. 2015. "Energy Price Reforms in the GCC - What Can Be Learned From International Experiences,". https://www.imf.org/external/np/pp/ eng/2015/111015b.pdf.

- 2017. "The Economic Outlook and Policy Challenges in the GCC Countries." GCC Surveillance Paper. IMF.

Kojima, Masami. 2013. "Petroleum Product Pricing and Complementary Policies: Experience of 65 Developing Countries since 2009.” Policy research working paper 6396. The World Bank.

Komives, Kristin, Vivien Foster, Jonathan Halpern, Quentin Wodon, and Roohi Abdullah. 2008. "Water, Electricity and the Poor: Who Benefits from Utility Subsidies." The World Bank. https://openknowledge.worldbank.org/ handle/10986/11745.

Kuwait Times. 2018. "No Plans for Kuwait to Raise Fuel Prices Again.” Kuwait Times, January 9, 2018. http://news.kuwaittimes.net/website/ no-plans-kuwait-raise-fuel-prices/.

Luong, Pauline Jones, and Erika Weinthal. 2010. Oil Is Not a Curse: Ownership Structure and Institutions in Soviet Successor States. New York: Cambridge University Press.

Mahdi, Wael, and Vivian Nereim. 2017. "Saudi Arabia Delays Energy-Subsidy Cuts.” Bloomberg.Com. https://www.bloomberg.com/news/articles/2017-07-06/ saudis-are-said-to-delay-energy-subsidy-cuts-amid-economic-pain.

Maxwell, Steve. 2010. "Market Outlook: Historical Water Price Trends." Journal (American Water Works Association) 102, no. 4: 24-28.

Moerenhout, Tom. 2018. "Energy Pricing Reforms in the Gulf: A Trend but Not (yet) a Norm." International Institute for Sustainable Development. https:// www.iisd.org/sites/default/files/publications/energy-pricing-gulf-trend-butnot-norm.pdf. 
Overland, Indra. 2010. "Subsidies for Fossil Fuels and Climate Change: A Comparative Perspective." International Journal of Environmental Studies 67, no. 3 (2010): 303-17. http://www.tandfonline.com/doi/abs/10.108 0/00207233.2010.492143?tab=permissions\&scroll=top.

Qatar General Electricity \& water Corporation. 2018. “Tariff”. https://www. km.com.qa/CustomerService/Pages/Tariff.aspx.

Rentschler, Jun, and Martin Kornejew. 2017. "Energy Subsidy Reforms and the Impacts on Firms: Transmission Channels and Response Measures." Oxford Energy Forum, no. 108: 16-19.

Rentschler, Jun, Martin Kornejew, and Morgan Bazilian. 2017. "Fossil Fuel Subsidy Reforms and Their Impacts on Firms." Energy Policy 108, no. Supplement C: 617-23. https://doi.org/10.1016/j.enpol.2017.06.036.

Saudi Electricity Company. 2018. "Consumption Tariff,". https://www.se.com. sa/en-us/customers/Pages/TariffRates.aspx.

Strand, Jon. 2016. The Economics and Political Economy of Energy Subsidies. MIT Press.

Sultanate of Oman. 2018. "National Subsidy System". https://nss.gov.om/site/ about? $\ln =\mathrm{en}$.

Times of Oman. 2018. "Fuel Prices for February 2018 Announced in Oman." Times of Oman. http://timesofoman.com/article/127292.

Victor, David. 2009. "The Politics of Fossil-Fuel Subsidies." SSRN ELibrary. http://papers.ssrn.com/sol3/papers.cfm?abstract_id=1520984.

Victor, David G., David R. Hults, and Mark C. Thurber, eds. 2011. Oil and Governance: State-Owned Enterprises and the World Energy Supply. Cambridge University Press.

Walker, Lesley, and Peter Kovessy. 2016. "Qatar Increases Petrol Prices from Midnight Tonight.” Doha News, January 14, 2016. https://dohanews.co/ qatar-increases-petrol-prices-from-midnight-tonight/.

Whitley, Shelagh, and Laurie van der Burg. 2015. "Fossil Fuel Subsidy Reform in Sub-Saharan Africa: From Rhetoric to Reality." Overseas Development Institute. http://newclimateeconomy.report/workingpapers/wp-content/ uploads/sites/5/2016/04/FFS-Reform-in-Africa_NCE-ODI_final.pdf. 
Open Access This chapter is licensed under the terms of the Creative Commons Attribution-NonCommercial-NoDerivatives 4.0 International License (http:// creativecommons.org/licenses/by-nc-nd/4.0/), which permits any noncommercial use, sharing, distribution and reproduction in any medium or format, as long as you give appropriate credit to the original author(s) and the source, provide a link to the Creative Commons licence and indicate if you modified the licensed material. You do not have permission under this license to share adapted material derived from this chapter or parts of it.

The images or other third party material in this chapter are included in the chapter's Creative Commons licence, unless indicated otherwise in a credit line to the material. If material is not included in the chapter's Creative Commons licence and your intended use is not permitted by statutory regulation or exceeds the permitted use, you will need to obtain permission directly from the copyright holder. 